\title{
Nowakowskiella moubasheriana sp. nov., a new cladochytrioid fungus from Poland
}

\author{
S. K. M. HASSAN"
}

Institute of Botany. Warsaw University. Warszawa. Al. Ujazdowskic 4

H a s 5 a n. S.K.M.: Nowakowskiella noubasheriana sp. nov., a new cladochyiriotd fungus from Poland. Acta Mycol. 19 (1): 77-82, 1983.

A new exooperculate species of Nowakowskiella has been described. The type strain has been isolated from the water sample taken from the small bog in the ash forest in the National Kampinos Park near Warsaw. The fungus developed on bits of onion skin the rhizomycelial growth and formed numerous zoosporangia and resting spores. It is considered by the author to be a new species of Nowakowskiella related to $N$. macrospora Karling, and named $N$. moubasheriana sp. nov.

In the course of the study of saprophytic chytrids in Poland a range of diverse forest water bodies and flows has been investigated by baiting the samples by bits of onion skin. One of these samples, taken from the big pool on the swampy ground near the high-way Warszawa-Nowy Dwór at Dębina at November 1981 after one month of incubation yeldied with a flourishing growth of aboundant rhizomycelium with zoosporangia and resting spores. Examination of the course of zoospore development, liberation and morphology showed that the strain represented a previously underscribed species of the exooperculate cladochytrioid fungus. Taking into consideration the lack of septa in the continuous elements of rhyzomycelium it has been decided, that the new species is a member of the genus Nowakowskiella. The fungus under consideration is described under the name Nowakowskiella moubasheriana, sp. nov. The name is given in the honour of Professor A. H. M o u b a s he r, mycologist of the Botany Department, Faculty of Science, Assiut University, Egypt.

*Permanent address: Botany Department, Faculty of Sciencex, Minia University, Minia, A. R. Egypt. 

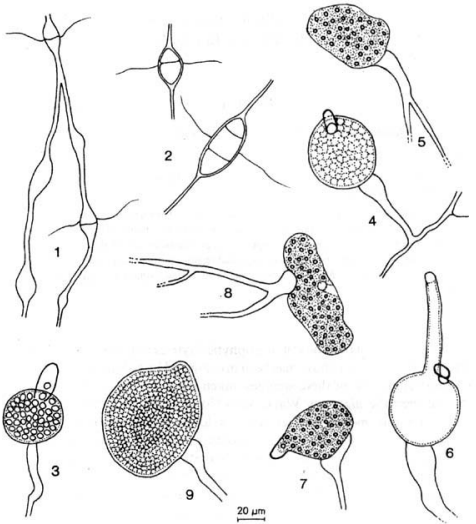

Figs. 1-9. Nowahowskiella moubasheriana

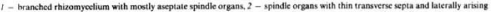
thiseids.3-6 - sphericul to broadly pyriform apophysate terminal zoosparangia, 7 - zoosporangium with smatl papilla-like tateral neck. 8 - transverally swollen zeesporangium, 9 - eoosporangian with bow lateral papilla 


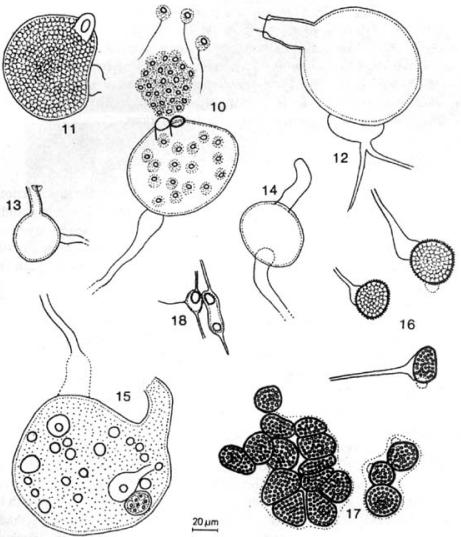

Figs 10-18. Nowakowskiella moubasheriana

10 - exo-operculate sporangium during zoospore Siberation, $11-13$ - zoosporangia with strixtly lateral necks. 14 - zoosporangium with apcal carved sock. 19 - exureme zoosperangium wis laseral curved neck, 15 - brownish thickwalled resting sporangia. 17 - smooth hyaline resting spores, 18 - young thall with pignented gjobule and first rhizoids 


\section{Nowakowskiella moubasheriana Hassan sp. nov.}

Rhizomycelium profusum, extensum, ramosum, 1-3 $\mu \mathrm{m}$ in diametro, filiforme, aseptatum, cum organis fusiformibus aseptatis vel rarior septatis, numerosis. Sporangia plurima, variabilia, apophysata, plerumquae sacciformia vel pyriformia vel sphaerica, 40-96 $\mathrm{mm}$ in diametro, saepe collum plus mimusquae elongatum habentia, ad $86 \mu \mathrm{m}$ longa: operculum externum. Zoosporae sphaericae, 9-10 $\mathrm{mm}$ in diametro, cum flagellis posterioris 45 longis et globulo refractivo pallido- luteolochloratho, 5-6 um in diametro. Sporae perdurantes apophysatae, globosae, laeve vel verrucosae, solitare vel angulatae, aggregatae, sine apophysis, laeve, 20-34 $\mathrm{mm}$ in diametro. Fungus aquaticus saprophyticus cellulosolyticus.

\section{Nowakowskiella moubasheriana Hassan sp. nov.}

Rhizomycelium profuse, moderately branched, rather fine, tenuous portions 1-3 $\mu \mathrm{m}$ in diameter, thin-walled, with mostly aseptate, thin-walled spindle organs $11-30 \mu \mathrm{m}$ long and $8-16$ in diameter (Fig. 1), sometimes spindle organs with 1 or 2 very thin transverse septa, and then bigger, $28-52 \mu \mathrm{m}$ long and $18-23$ in diameter (Fig. 2); rhizoids very thin, abundantly branched, arising from the tenuous portions as well as from the spindle organs. Zoosporangia mostly terminal and apophysate, usually more or less rounded, from spherical to broadly pyriform, $45 \cdot 54 \mu \mathrm{m}$ in diameter and up to $60 \mu \mathrm{m}$ long, (Figs. $1-6$ when measured without the neck), but very often bigger and elongated transversely to apophysis (Figs. $7-15$ ), and then $50-122 \mu \mathrm{m}$ in diameter and $48-109 \mu \mathrm{m}$ long, in the extreme case (Fig. 8) even $96 \mu \mathrm{m}$ in diameter and only $37 \mu \mathrm{m}$ high; the neck mostly lateral (Figs. 7,9,11,12,13 and 15), but often apical, rather long, up to $76 \mu \mathrm{m}$, and wide $9-14(-24) \mu \mathrm{m}$ in diameter, usually isodiametric and straight, but sometimes locally swollen or curved (Figs. 12,14,15); sometimes the neck is shorter, papillalike, (Figs. 6, 7,11); operculum external, dish-like, shallow, thin-walled, up to 12 $\mu \mathrm{m}$ in diameter (Fig. 10). Apophysis thin-walled, from very elongated, narrow and indistinct, up to $8 \mu \mathrm{m}$ in diameter, to nearly spherical or pyriform, 16-18 $\mu \mathrm{m}$ in diameter and about $21 \mu \mathrm{m}$ long or sometimes transverse, over $30 \mu \mathrm{m}$ in width by ca $10 \mu \mathrm{m}$ high (Fig. 12). Sporangia sometimes becomes light brownish, thickwalled, verrucose and dormant (Fig. 16), usually over $30 \mu \mathrm{m}$ in diameter. Zoospores slowly ooze out and form a globular mass at exit orifice, spherical, 9 $10 \mu \mathrm{m}$ in diameter, with large, 5-6 $\mu \mathrm{m}$ in diameter, slightly yellowish to dirtygreenish, anterior, plastic refractive globule and flagellum up to $40 \mu \mathrm{m}$ long; sometimes part of zoospores leave the sporangium singly and swim away immediately. Apart from the verrucose, apophysate resting sporangia, smooth, angular, hyaline resting spores of unknown origin, up to $30 \mu \mathrm{m}$ in the greatest dimension, are formed collectively inside (?) the very thin-walled evanescent containers (Fig 17). 

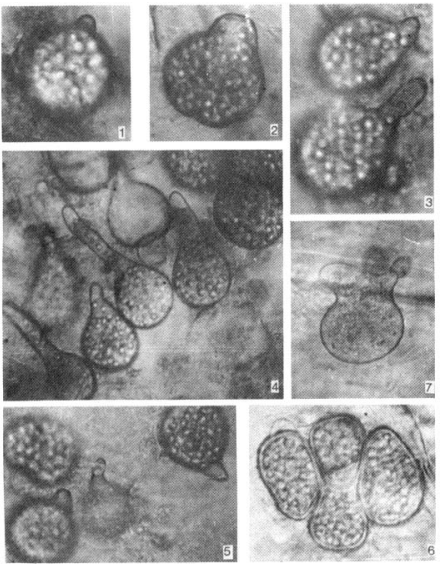

$20 \mu \mathrm{m}$

Nowakowskella mesahasheriana

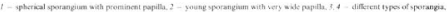

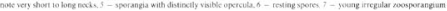


Saprophytic in sphagnum-bog water near Dębina near Warsaw (type locality), isolated in November 1981 on onion skin bait, Poland.

Type: slide no 25705 deposited in the Herbarium of the Institute of Botany, Warsaw University, Warszawa, Poland.

Iconotype: Figs. 1-18 in the present paper and Plate I.

The yellowish or dirty-greenish pigmentation of the zoospore globule appears early in the zoospore development, from the beginning of the formation of these globules inside the ripening sporangium (before zoospore cleavage). This colouring persists during the whole period of the zoospore motility. After the zoospore comes to rest on the substrate and encysts, the globule even grows attaining about $8 \mu \mathrm{m}$ in diameter or dividing. The young thallus (Fig. 18) consists of the rounded or elongated primordium equipped with usually two opposite rhizoidal axes and thinner and shorter lateral thread-like rhizoids. During the next stage of development this primordium becomes the spindle organ and the pigmentect globule disappears.

The most marked feature of this species is the big zoospore attaining $10 \mu \mathrm{m}$ in diameter and containing an extremely large refractive globulc. Zoospores of comparable dimensions form only two previously described species: $N$. ramosa Butler (6,6-8,8 $\mu \mathrm{m}$ in diameter with the globule up to $3 \mu \mathrm{m}$ in diameter) and $N$. macrospora Karling (10-12 $\mu \mathrm{m}$ in diameter with a globule $3-5 \mu \mathrm{m})$. Resting spores of $N$. ramosa are very similar to resting sporangia of N. moubasheriana, but they are formed by budding from the cells of pseudoparenchyma - structure lacking in my fungus. Moreover - N. ramosa differs from the species described here sharply by its tubular, coarse, occasionally septate rhizomycelium (B u tle r 1907, S par r ow 1960, K a r $1 \mathrm{ing} 1977$ ). Taking into account the general appearance and structure of the rhizomycelium $N$. macrospora is more similar to the fungus under consideration. The two fungi differ in the following characters: zoospores of $N$. macrospora are bigger, with mostly basal, disc-like, hyaline and relatively smaller refractive globule and contain few smaller grains in the basal part of the body; its spindle organs are always aseptate, operculum is usually shallowly sunken and apiculate or hat-shaped and resting sporangia are smooth and darker (K a r 1 in g 1945, 1977, S p a r r o w 1960). N.macrospo$r a$ is rather common in Poland and has been recorded from Warsaw and surroundings previously by the author as well as earlier by R o g o s (1979) and comparison of these findings with the fungus described in the present paper permit to conclude, that they are clearly distinct, although closely related.

I am greatly grateful to my supervisor Doc. dr hab. Andrzej B a t k o, Institute of Botany. Warsaw University, for his kind and continuous guidance as well as preparing the latin diagnosis. 


\section{REFERENCES}

B u t I e r Edwin J., 1907. An account of the genus Pythizm and some Chytridiaceae, Mem. Dept. Agr. India, Bot. Ser. 1: 1-160, pls. 1-10.

K a f I i g J. S, 1945, Brazilian chytrids. V. Nowakowskiella macrospora n. sp., and other polycentric species, Amer. J. Bot. 32: $29-35$.

K a r I ing J. S, 1977. Chytridiomycetarum Iconographia. Vaduz. 444 p.

R o g o \& J, 1979, Badania nad grzybami blonnikolubnymi Parku Lazienkowskiego, (Investigation on fungi from Lazienki Garden growing on cellulosic substrates), M. Se. Thesis, Institute of Botany, University of Warsaw, Warsaw, Polund.

Sparrow F. K. Jr., 1960, The aquatic Phycamycetes. 2nd ed. Univ. of Michigan Press, Ann. Arbor, Mich. $1187 \mathrm{p}$.

\section{Novakowskiella moubasheriana sp. nov.}

\section{Streszezenie}

Autor wykryl w wodzic zatorfionego zagiçbienia gruntu w legu Kampinoskicgo Parku Narodowego koło Dębiny nowy gatunek blonnikolubncgo grzyba wodnego - Nowakowshiella moubasheriana Hassan, sp, nov. Grzyb ten jest zblizony do $N$. ramosa B u $t$ I e r (1907) i szczególnic - do N. macrospora K a r l i n g (1945), gatunków notowanych weześniej z Warszawy i okolic przez autora oraz R o g o s (1979), leez różni się wyraźnie pigmentacją ziarna Í́niącego zoospory oraz szezegslami morfologii plechy i zarodni. 